\title{
David Bromell
}
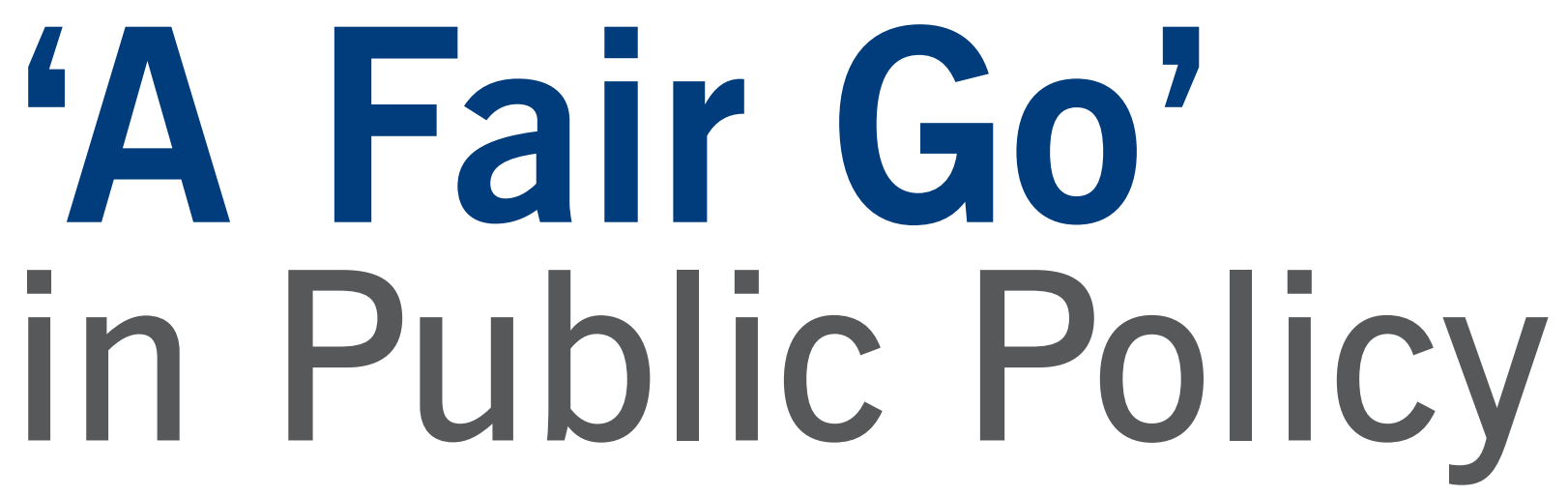

Introduction

In the context of the 2013 retirement income review (CFLRI, 2013), Kathryn Maloney and Malcolm Menzies from the Commission for Financial Literacy and Retirement Income put the question to me: what does 'a fair go' mean in public policy? ${ }^{1}$ I mentioned this in a chance conversation with Colin James, who suggested tackling the question in an active, verbal sense ('a fair go'), rather than attempting to elaborate on 'fairness' as an abstract noun. Consequently, this paper does not propose 'a theory of fairness' as a proxy for, say, a theory of distributive justice, or a theory of social justice, even a non-ideal theory of justice (cf. Arvan, 2014; Simmons, 2010). My aim is more modest: to provide a framework for public reasoning in contexts where there is argument across the political spectrum about whether a public policy gives people who are affected by it 'a fair go'. This approach is based on three assumptions.

David Bromell is a Senior Associate of the Institute for Governance and Policy Studies. He lectures in political philosophy and public policy in the School of Government. Since July 2013 he has been a Principal Advisor in the Strategic Policy team at Environment Canterbury. Previously he was a Principal Advisor and acting Chief Policy Advisor in the Ministry of Social Development.
1. A great deal of public policy-making involves arguments about who gets what, when and how, relative to others, and who pays (cf. Laswell, 1950).

2. These arguments take place within a society that exhibits deep diversity, including a plurality of values. People do not necessarily want, or value, the same things to the same extent, in the same way (Bromell, 2009a). ${ }^{2}$

3 There is not and never will be a perfectly just world, or a perfect social system, or a perfect set of institutional arrangements and regulations. As Sen (2009) has argued, we need to abandon pretensions to 'transcendental institutionalism' and focus instead on advancing justice, rather than perfecting it. He proposes 'government by discussion': the exchange of public reasons to arrive at partial rankings and limited agreements about practicable options to make life better for people than it is now.

Etzioni (2014) has similarly urged us to view public policy as a fixer-upper, rather than a new construction. Policy- 
making is less about defining a goal, considering options to get there and implementing the most cost-effective option than it is about asking what can be done with the conditions we have been given and the unfolding trends we may ride, and working out how we might make things better than they are now, within the resources at our command. Thus the argument that follows is based on a further (fourth) assumption:

4 The vast majority of public servants, whether elected or appointed, enter public life not for the naked exercise of power, nor predominantly to satisfy and advance our own interests, but because we want to make a difference and improve outcomes for our fellow citizens as well as ourselves.

\section{Making sense of moral judgements}

Something of a consensus has emerged in recent years between anthropologists, animal behaviourists, psychologists, neuroscientists, game theorists and behavioural economists that a concern for fairness is a 'wired' trait in humans (Alesina and Angeletos, 2005; Fehr and Schmidt, 2003; Gazzaniga, 2005; Pfaff, 2007; Hausman, 2008; Crockett, 2009; Corning, 2011). This trait has also been found to exist, at least rudimentarily, in some non-human primates (Brosnan and de Waal, 2003; Bräuer and Hanus, 2012). The norm of fairness seems to be universal, and a product of both nature and nurture, like the acquisition of language. Like language, development occurs as children mature from reliance on simple decision rules (equal shares, taking turns, tossing a coin, drawing straws) to more complex considerations of age, merit, social relationships and 'us/them' distinctions, all shaped by the values, customs, rules, stories and practices of a given society (Almås et al., 2010; Corning, 2011, p.7).

Corning (2011) concludes that 'altruistic sharing backed by a threat of punishment for selfish violations is a fundamental element of human nature, coupled with the strong expectation for reciprocity from others'. Accordingly, he argues that 'the standard neoclassical economics model of a rational, calculating, acquisitive economic man
(Homo economicus) is a caricature that obscures a much more complex reality' (Corning, 2011, pp.9, 82; cf. Sen, 1977).

In other words, the moral judgement 'that's not fair' is first a feeling, an emotional reaction, voiced as an objection to an actual or proposed state of affairs or distribution of benefits and costs. Emotions play a more prominent role in social decision-making than we often care to admit (Sanfey, 2007; cf. Hume, 1777, part I, opening para.). As Haidt (2012, p.48) puts it, 'Moral reasons are the tail wagged by the intuitive dog'. We characteristically proceed from an emotion or intuition to a moral judgement ('fair enough'/'that's not fair'). sav, fair's fair. Consider, for example, the extraordinary longevity of the consumer affairs television programme Fair Go, which first screened in 1977 and is one of New Zealand's longest running and highest rating programmes.

On a visit to New Zealand, historian David Fischer noticed how frequently New Zealanders talk about fairness, and reflected on his fellow Americans' characteristic preoccupation with liberty or freedom. In an extended comparative study (Fischer, 2012), he explains this in two ways. First, the United States and New Zealand are products of different waves of imperial expansion, in reaction to different social conditions and pressures.

\section{The notion of 'a fair go' is, of course, relevant not only to retirement income policy ... but also to matters as diverse as poverty, income inequality and redistribution}

Only when we ourselves have second thoughts, or are challenged by others, do we apply reasoning, somewhat after the fact, in order to explain and justify our moral judgements to ourselves and to others.

I have argued elsewhere (Bromell, 2012) that public policy-making needs to go beyond ostensibly 'values-free', empirical analysis of 'the evidence' and 'what works', and find ways to engage in co-production with citizens of the sort that factors into policy making explicit critical reflection and public deliberation on purpose, values and emotions. Freiberg and Carson similarly invite us to recognise emotion and affect within 'a reasoned and open dialogic process of policy formulation' (Freiberg and Carson, 2010, p.161).

\section{A Kiwi preoccupation}

A 'wired' concern for fairness is amplified in the New Zealand context by a cultural preoccupation with 'a fair go' that is reflected in everyday habits of thought and speech: a fair go, fair play, fair share, fair enough, fair game, a fair shake of the
The United States was settled in the 17th century by people who felt themselves to be victims of tyranny and persecution. Consequently they elevated the principle of liberty. ${ }^{3}$ New Zealand on the other hand, was settled in the 19th century by people who felt they were victims less of tyranny than of social injustice and gross inequity. Consequently they elevated the principle of fairness.

Secondly, the US and New Zealand afforded different material conditions. In the US, many Americans continue to have a sense of boundlessness and opportunity ('Go west, young man!'), of living in 'the land of the free' in a universe without limits. In New Zealand the young nation quickly ran up against resource constraints. Climate and soil were not as kindly as first thought, and survival depended on developing cultural norms, social practices and political institutions to encourage and enable fairness, sharing and redistribution. Anne Salmond notes, for example, that:

In their dislike of the aristocratic monopoly of land and waterways 
Figure 1: Occurrence of 'fair' and its cognates in 2008 and 2011 general election party manifestos ${ }^{4}$

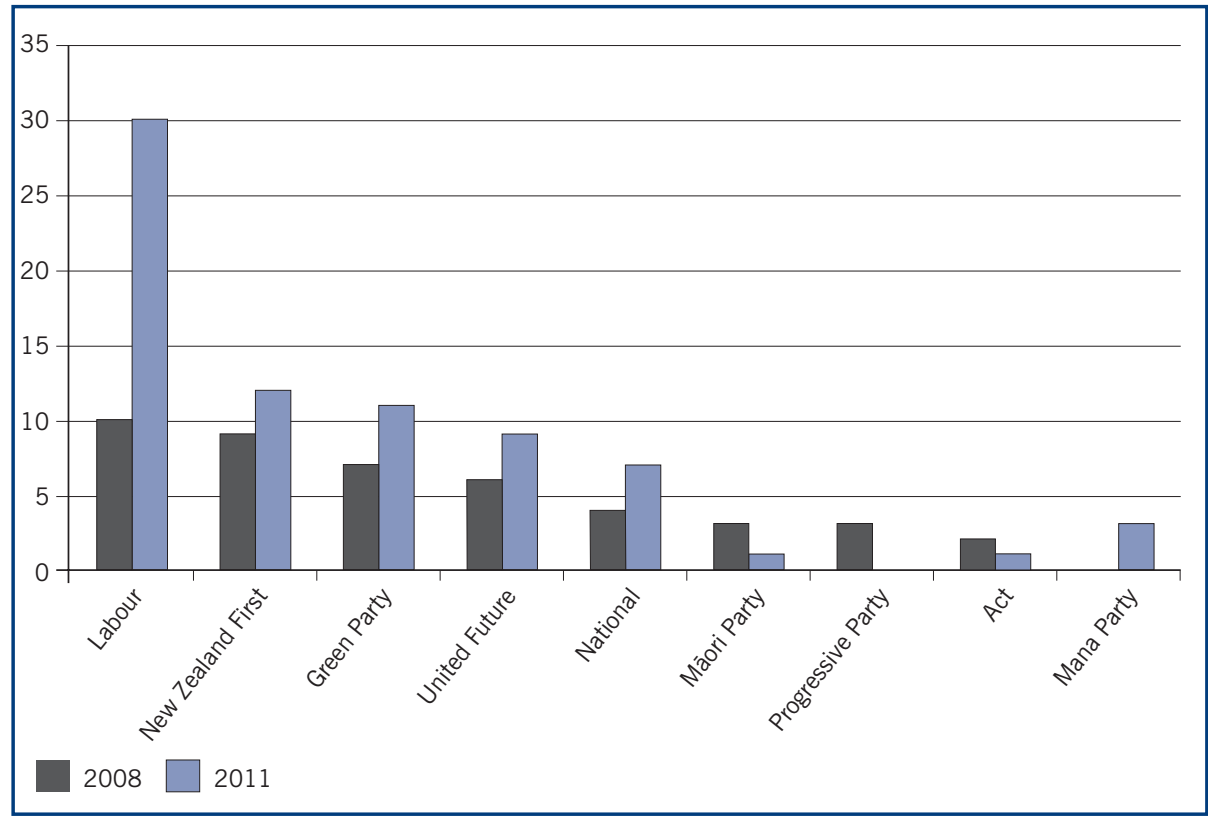

at home, the settlers fought for the establishment of the Queen's Chain, and made successive attempts to break up large estates. Part of their legacy is the idea of the 'fair go', a powerful motif in our society, along with a marked dislike of arrogance and pretension. (Salmond, 2012, p.4)

\section{Policy relevance and political rhetoric}

The notion of 'a fair go' is, of course, relevant not only to retirement income policy - the context in which the question was first put to me - but also to matters as diverse as poverty, income inequality and redistribution (Rashbrooke, 2013; Stiglitz, 2013); education; housing; health care and medical rationing (Koch, 2002), including access to pharmaceuticals (Coyle, 2012); settlement of historic Treaty of Waitangi grievances; sentencing guidelines; resource management, including the use of fresh water; risk management in the use of new technologies (McComas and Besley, 2011); and the sale of shares in stateowned assets (Salmond, 2013). Fairness is critical for the stability and sustainability of public policy (Alesina and Angeletos, 2005 , p.974). If regulation is perceived to be fair, it is more likely to win cross-party support and less likely to be subsequently amended or repealed.

Given its currency as a vernacular concept in New Zealand, political rhetoric commonly appeals to 'a fair go'.
For example, 'a fair go for the ordinary [or 'decent'] bloke' was a favourite slogan of 'Rob's Mob' and Sir Robert Muldoon when he was prime minister and leader of the National Party from 1975 to 1984. (Perhaps it is fortunate that 'Rob's Mob' did not elaborate on its aspirations for 'the ordinary woman') The 1986 Royal Commission on the Electoral System identified ten criteria for evaluating electoral systems, with many involving 'fairness' - to Māori, to ethnic minorities and to political parties: 'For New Zealanders an electoral system - and, more broadly, a political system, or a set of government policies - is defensible only if seen to be "fair"' (Levine, 2012).

More recently, the words 'fair', 'unfair', 'fairness' and 'fairly' were used 74 times in political party election manifestos in 2011 , an increase of $68 \%$ over their use in the 2008 election.

While questions are increasingly asked about whether New Zealanders do indeed get 'a fair go' (Kilgallon, 2013), the concept of fairness still resonates and continues to be used in political rhetoric. For example, David Clark, candidate and subsequently (following the 2011 election) MP for Dunedin North, wrote a blog post in August 2010 that argued:

The reason people choose to stay in New Zealand, or return to New Zealand, is tied up with the type of society we have. People love New Zealand because they feel at home here. You and I value access for everyone to quality health care. All New Zealanders value schools that are safe with dedicated teachers, and an education system that delivers quality results for our kids. These values are rooted in the fact that New Zealanders have an underlying sense of fairness. It is what makes New Zealanders tick. We love to see everyone having a fair go. Our pride in our identity as New Zealanders is tied up with a sense of fairness. (Clark, 2010)

In everyday discourse and in political rhetoric, New Zealanders seem to appeal more commonly to 'a fair go' than to 'rights' or to some or other theory of justice. This may have wider significance. The notion of 'a fair go' appears to bridge a gap between more abstract accounts of political principles and the actual beliefs - and actions - of political actors (Klosko, 1992, p.xii). As Sen notes, 'we have good reason to be persuaded by Rawls that the pursuit of justice has to be linked to - and in some sense derived from - the idea of fairness', which is foundational and in some sense prior to development of principles of justice (Sen, 2009, p.54). It may be more productive, therefore, to think critically about what 'a fair go' means in public policy and to structure policy debate in these terms, than to attempt to assess or justify policy options in terms of 'rights' (Walzer, 1981; cf. Geiringer and Palmer, 2003, 2007) or by appeal to some or other theory of justice.

While New Zealanders seem to value the idea of 'a fair go', we do not often pause, however, to bring to this explicit critical reflection or to clarify what 'a fair go' means in public policy (Kerr, 2005, p.23). The remainder of this article provides a framework for public reasoning and comparative assessment of 'a fair go' in public policy.

\section{Context, relationships, time}

The framework I propose is designed to facilitate an exchange of public reasons where there is argument about what 'a fair 
go' means in relation to a specific policy or set of policies. It is important, therefore, to clarify at the outset the context, relationships and temporal dimensions of the policy problem. What is fair depends on the people who are the participants, and their relationships and interactions within a specific context at a particular point in time (Corning, 2011, p.19; Fleurbaey and Maniquet, 2011, p.234):

Context: In what context has the question of 'a fair go' arisen? What do we want to change? What are the goals (outcomes) and objectives (results) we want to achieve?

Relationships: Who are the key 'stakeholders' (interested and affected parties)? What is the nature of the relationship between them? Are there existing agreements, contracts or treaties between the parties?

Time: What time constraints do we face? What time trends can we observe, and what are the implications of those trends now and in the future? How are costs and benefits currently allocated between past, present and future generations?

\section{Fair process}

The next stage in my argument is to consider, in the context of public policymaking in a liberal democracy, what 'a fair go' requires procedurally, because 'how things work' is as important as 'what works'. The procedures that govern public services, and the perceived fairness of how rules are set and implemented, can significantly determine public responses: 'These responses can condition trust in public services, and determine how willing people are to cooperate with service providers: cooperation that, in turn, can be crucial to achieving the objectives of a service' (Pearce, 2007, p.11). Fair process requires impartiality (equal consideration of interests), deliberative fairness (how the rules are set), transactional fairness (how the rules are operationalised and playing by the rules once set) and transitional fairness (how rules are revised or repealed, and the timing of policy implementation).

\section{Impartiality}

Impartiality declines to introduce private considerations into decisions that should be made on public grounds (Barry, 1995, p.13). It respects equality of moral worth, equal consideration of interest - i.e. 'democratic equality' (Anderson, 1999) and principles of natural justice. Justitia wears a blindfold when she weighs our competing interests and passes judgement. Everyone counts for one, and none counts for more than one - a foundational, and at the time radical, idea in Bentham's utilitarianism.

Impartiality is why we have due process, and formal separation of powers between the monarch or head of state, the legislature and the judiciary. Impartiality democracy, or government by discussion, in which eligible citizens and permanent residents participate in the proposal, development and creation of laws, either directly, or indirectly through the free and fair election of representatives.

Deliberative fairness requires commitment to public justification: Rawls' 'reflective equilibrium' 'overlapping consensus' (Rawls, 2001, pp.29-38 and 2005, pp.133-72), or Sen's 'open' (as opposed to 'closed') impartiality (Sen, 2009, pp.124-52), together with the social, economic and cultural conditions that enable the free and equal participation of citizens in political self-determination.

Deliberative fairness requires an exchange of public reasons, given the

\section{Administrative consistency is part of what we examine when asking whether someone is getting 'a fair go' in public policy.}

is why public sector ethics matters. There is, or should be, no place in public policy for mates' rates, special access to decision makers and backroom deals.

Fairness as impartiality precludes permanent special group rights, including special political representation based on ancestry or ethnic identity (Bromell, 2008, 2009a, 2009b). As Brian Barry argues in presenting his theory of justice as impartiality:

The underlying assumption here is that claims to special advantages based simply upon membership of a certain bloodline, ethnic group or race are too transparently selfserving to form a basis of agreement that others can seriously be asked to assent to. More deeply, the whole idea that we should seek the agreement of everybody rests upon a fundamental commitment to the equality of all human beings. (Barry, 1995, p.8)

\section{Deliberative fairness}

Secondly, 'a fair go' requires deliberative fairness, which is about how the rules are set. Deliberative fairness is why we have inevitable arguments about what 'a fair go' means in any particular case. For this reason a government may publish a 'white paper' or discussion document and receive submissions from the public. Parliament, through the select committee process, invites and hears submissions on legislation before the House. Parliamentary debates test the rationale for policy change. The media interview politicians and probe the reasons for doing this and not that.

The question 'is it fair?' is illuminated, Barry (1995, p.113) suggests, by phrasing it as, 'could it reasonably be rejected?' As Barry points out, appeal to public reason does not, however, restrict us merely to logical deduction in the public sphere, or to ostensibly 'neutral' or 'value-free' language and modes of reasoning and communication (cf. Bromell, 2011; Bradstock, 2010, 2012; Boston, 2013):

Historically, reason has been contrasted with authority, prescription, revelation, or coercion as a basis for the justification of institutions. In this context, 'reason' means reasoned argument, from premises that are in principle open 
to everyone to accept. We can add a contemporary gloss to this by saying that these are premises which reasonable people, seeking to reach free, uncoerced agreement with others, would accept. (Barry, 1995, p.7)

Amartya Sen has similarly argued that:

Rationality is in fact a rather permissive discipline, which demands the test of reasoning, but allows reasoned self-scrutiny to take quite different forms, without necessarily imposing any great uniformity of criteria. If rationality were a church, it would be a rather broad church. (Sen, 2009, p.195)
General, select committee hearings, the Privileges Committee of Parliament, parliamentary commissions and inquiries, appeals and tribunals, parliamentary questions, televised parliamentary debates and the publication of Hansard. Transactional fairness is about keeping the buggers honest.

\section{Transitional fairness}

Fourthly, fair process requires reasonableness in how rules are changed or repealed, and, in particular, the timing of policy implementation. The 1988 Royal Commission on Social Policy reflected that:

Changes must be able to be implemented in an orderly manner which does not cause undue disruption to the lives of

\section{... we need to arrive at a social evaluation of what 'a fair go' means in a specific context, at a particular point in time, through negotiated agreement ... of alternatives ...}

\section{Transactional fairness}

Thirdly, transactional fairness is about how rules are operationalised and about playing by the rules once set. Implementation planning frequently involves communications with people who will be affected by new or changed rules. There may be a phase-in, or amnesty, period, but within a reasonable period of time we expect the same rules to apply to people in the same situation in the same way. Administrative consistency is part of what we examine when asking whether someone is getting 'a fair go' in public policy.

Playing by the rules once set also requires transparency and rights of review and appeal. This is why it is important to preserve the independence of the judiciary. It is why we have legislation like the Official Information Act 1982, the Local Government Official Information and Meetings Act 1987 and the Public Finance Act 1989. It is why we have the ombudsmen, the Office of the Auditor-

New Zealanders; nor should they undermine people's legitimate expectations of security and certainty, and, too, of the role that government plays in their daily lives. It is also important that the reasons underlying the proposed changes are understood in the community. (Royal Commission on Social Policy, 1988, vol. 2, p.740)

Retirement income policy is one example. If a government were suddenly to change the policy settings for New Zealand Superannuation without any transitional period, a cohort of older people would be affected with no time or opportunity to prepare for changes to the amount of entitlements, criteria or age of eligibility. And any transition from a payas-you-go (PAYGO) system to a save-asyou-go (SAYGO) system would need to be managed carefully to avoid the transition generation being called on to pay twice: once for their parents' generation, and once for their own retirement. As Ross Guest argued in a background paper prepared for the 2013 retirement income policy review:

People's income tends to be highly variable over their lifetime. They prefer to have much less variability in their consumption. But in order to smooth their consumption they need to be able to make plans, which requires stable policy. Some change is inevitable but policy stability requires that change occur after due deliberation and that people have adequate time to adjust. (Guest, 2013, p.25)

Another example is tertiary education funding policy for student support. Changing the eligibility or amount of student allowances, or the terms and conditions of student loans, is bound to raise questions of transitional fairness and intergenerational equity, particularly where students have committed to a lengthy period of education and training.

\section{Fair outcomes}

'A fair go' in public policy requires more than fair process. Outcomes, or results, also matter and need to be seen to be fair, and especially our outcomes relative to one another. As Bräuer and Hanus note, 'Humans have a sense of fairness, i.e. an interest in the ideal of equity. This sense allows them to compare their own efforts and subsequent outcomes with those of others, and thus to evaluate and react to inequity'(Brauer and Hanus, 2012, p.256, emphasis mine).

Fair outcomes cannot, however, be defined in the abstract, in advance, once and for all. Rather, we need to arrive at a social evaluation of what 'a fair go' means in a specific context, at a particular point in time, through negotiated agreement (based on public reasoning) of alternatives that can be concretely realised and that take account of the values and priorities of the people involved, and of relativity or interpersonal comparison. As Harry Frankfurt opens his paper on 'Equality as a moral ideal': 
First man: 'How are your children?' Second man: 'Compared to what?' (Frankfurt, 1987, p.21)

I am thus arguing for Sen's 'realisationfocused comparison' through the exercise of practical judgement, rather than the sort of 'transcendental institutionalism' (Sen, 2009, introduction) whereby technocrats set out to create a 'perfectly just' system or arrive at 'a single, uniquely rational, determinate answer' (Gauss, 2010, p.64). Moreover, as Klosko reminds us, 'because of the inevitable imperfection of all social arrangements, a certain measure of unfairness should be expected and accepted' (Klosko, 1992, p.66).

There are at least two ways we might proceed, both of which require comparative assessment of policy options against each other and the status quo. The first approach is to assess the substantive fairness of policy options by the extent to which they contribute, or might reasonably be expected to contribute, in a significant and measurable way to an overall increase in well-being and to improvement in the distribution of well-being. The second approach is to assess the substantive fairness of policy options against the extent to which we can reasonably expect them to actualise an agreed set of values or normative precepts.

These two approaches are not mutually exclusive, and there is no reason why both might not be employed within a framework for comparative assessment and public deliberation. It is important, however, to keep any such framework at a relatively high level, and to avoid overspecification that becomes restrictive or exclusionary.

\section{Living Standards Framework}

To adopt the first approach (a policy is substantively fair if it improves overall well-being and the distribution of wellbeing), we might assess fair outcomes against the five dimensions of the Treasury's Living Standards Framework (Treasury, 2013): economic growth, sustainability for the future, increasing equity, social infrastructure and reducing risks. The Treasury framework uses a capital stocks and flows approach (i.e., financial and physical capital, natural capital, social capital and human capital) to enable evidence-informed evaluation along these lines:

Economic growth

- Does this [policy or set of policies] improve the opportunities or incentives for higher incomes or greater economic growth?

- Does this remove obstacles that hinder resources moving to their most efficient use, or enhance the ability of people to take up new opportunities?

Sustainability for the future

- Does this impact on the capital stocks for future use (e.g. physical capital, human capital, or the sustainability of the environment?)

Increasing equity

- Does this impact on the distribution across society (both intra- and is more likely than alternative policies to achieve better results across these five dimensions, then we might arrive at a working agreement that a policy is substantively 'fair'. A particular policy, or set of policies, gives the people affected by it 'a fair go' when it improves their overall well-being, and the distribution of wellbeing, now and in the future.

\section{Values-based assessment}

An alternative (or additional) approach is to assess the substantive fairness of a policy by reference to an agreed set of values or normative precepts. Proceeding in this way prompts explicit deliberation on the kind of society we want to create, inhabit and bequeath to the next generation, and the quality of life we wish to enjoy with one another now and in the future. Corning proposes a biosocial contract based on

\section{Public policy should promote and facilitate 'reciprocity between the state and its citizens and among citizens themselves' ... so that together we can live, live well and live better.}

intergenerational)?

- Does this improve opportunities for people to improve their position?

Social infrastructure

- Does this impact on core institutions that underpin our society (e.g. trust in the rule of law, democracy, Crown-Māori relationship, cultural identity)?

- Does this impact on the trust and connections between people?

Reducing risks

- Does this impact on New Zealand's ability to withstand unexpected shocks?

- In particular, does this impact on our macroeconomic position (debt, deficits, inflation, etc.)?

In other words, if there is agreement that the five dimensions of the Living Standards Framework broadly capture outcomes desired by a majority of New Zealanders, and that a particular policy three normative precepts in his book on 'the fair society':

- Goods and services must be distributed to each of us according to our basic needs (in this there must be equality).

- Surpluses beyond the provisioning of our basic needs must be distributed according to 'merit' (there must also be equity).

- In return, each of us is obligated to contribute proportionately to the collective survival enterprise in accordance with our ability (there must be reciprocity). (Corning, 2011, p.154)

Isbister (2001), in envisioning social and economic fairness, appeals to three dimensions of social justice, noting that these can and do conflict with each other: 'People deserve to be treated as equals, they deserve to be free, and they deserve 
to get the best they can out of their limited resources' (Isbister, 2001, p.4).

Any selection of values or moral precepts for the sort of deliberative framework I am proposing will inevitably be somewhat arbitrary. The values set needs to be sufficiently 'broad church' to enable people with diverse conceptions of the good, and rival political theories, to engage with one another in 'realisationfocused comparison'. (Imagine, for example, a utilitarian, a libertarian, an egalitarian and communitarian engaged in debate about which policy is most likely to give people 'a fair go'.) The point is not that the values set be comprehensive, but that it resonate sufficiently with a broad range of protagonists to keep them 'at the table' long enough to arrive at a practical political consensus, so that decisions can be made and action occur.

With this in mind, I propose four values for starters: freedom, equity, efficiency and reciprocity.

\section{Freedom}

Freedom can be understood both negatively (freedom from ... oppression, discrimination, domination, humiliation or disrespect) and positively (freedom for ... and freedom to ... the capabilities to lead a life one has reason to value) (Berlin, 1969; Honneth, 2004; Sen, 1999, 2009, pp.225-68; Pettit, 2008). Negative freedom requires us to reflect on whether a policy once operationalised intrudes to an unjustifiable extent on the liberty of the individual. Positive freedom requires us to factor in the social, economic and cultural conditions that enable people to pursue their own conceptions of the good. As Anderson notes:

Libertarians tend to identify freedom with formal, negative freedom; enjoying the legal right to do what one wants without having to ask anyone else's permission and without interference from others. This definition of freedom neglects the importance of having the means to do what one wants. (Anderson, 1999, p.315)

Critical enablers of positive freedom are access over a complete life to primary health care, education and training, appropriate housing, and opportunities to engage in meaningful paid work. This in turn implies that our pre-eminent social obligation in 'a fair society' is first to meet the basic needs of our fellow citizens (Corning, 2011, ch.7).

\section{Equity}

After basic needs are met and the enablers of democratic equality are assured, 'a fair go' requires equity in the sense of proportional equality in the distribution of costs and benefits. Equity does not mean treating everyone equally. (I have incorporated equality in the assessment of fair process: impartiality in the sense of equality of moral worth, and equal consideration of interests.) In considering the distribution of benefits and burdens, equity takes account of factors such as age (Atkinson, 1983, ch.7), needs, luck (Dworkin, 1981), agreements (e.g. treaties), merit, effort and contribution. It allows for social recognition of unequal needs, unequal talents and abilities, unequal application of those abilities, and unequal contributions to the common good: 'No doubt talented people do not deserve any moral credit for their native talents. But they do deserve moral credit for developing their talents and using them for our common benefit' (Harsanyi, 2008, p.74, emphasis his). ${ }^{5}$

Fairness thus requires breadth of consideration (Hooker, 2005). It requires us to distinguish between different sources of inequality, rather than assuming that everyone should necessarily have, or get, the same. Equity also challenges us to consider the intergenerational accumulation of advantage and disadvantage, in order to ensure that future as well as present generations get 'a fair go'.

\section{Efficiency}

Efficiency requires us to make the best use of available resources to achieve desired social ends (Isbister, 2001, p.21). Sometimes we talk about this as 'cost effectiveness' or 'value for money'. A policy that expends public monies to little good effect, or that uses inefficient means to achieve a good that might have been achieved at less cost, does not deliver 'a fair go' either to the recipient of the service or to the taxpayers who fund it.
Including efficiency in the assessment of 'a fair go' protects against a risk highlighted by Kaplow and Shavell: 'virtually any method of evaluation that gives weight to notions of fairness will sometimes lead to choices that make all persons worse off' (2002, p.xviii). Indeed, there seems little to commend a policy option if there is another policy option that is likely to produce or contribute to greater well-being for everyone (Fleurbaey and Maniquet, 2011, p.235). ${ }^{6}$ Zajac argues that:

all other factors being equal, one might consider economic efficiency to be a necessary fairness condition in any reasonable definition of fairness, while granting that, depending on the definition of fairness, some economically efficient allocations may be fairer than others. ${ }^{7}$ (Zajac, 1995, p.14)

\section{Reciprocity}

Reciprocity means give and take, over a complete life, with opportunities to belong, participate and contribute to the collective enterprise proportionately in accordance with our ability (Corning, 2011, p.154). Public policy should promote and facilitate 'reciprocity between the state and its citizens and among citizens themselves' (Conrad, 1981, p.19), so that together we can live, live well and live better. As Rawls puts it, 'we are not to gain from the cooperative labors of others without doing our fair share' (Rawls, 1971, p.112).

Reciprocity does not, or ought not, occur only between 'people like us' or near neighbours within the immediate circle of our moral concern. Reciprocity challenges us to transcend tribalism, embrace our common humanity and expand the 'we' (Singer, 1982). In response to large-scale natural disasters, for example, we commonly witness reciprocity at work between, and not only within, nation states.

Reciprocity makes 'a fair go' sustainable. As Barry notes: 'If I am motivated by a desire to behave fairly, I will want to do what the rules mandated by justice as impartiality require so long as enough other people are doing the same. Thus, people motivated by fairness reinforce 
Table 1: Things to think and talk about when assessing 'a fair go' in public policy

\begin{tabular}{ll}
\hline UNDERSTAND THE POLICY CONTEXT AND IDENTIFY GOALS AND OBJECTIVES \\
\hline Context & In what context has the question of 'a fair go' arisen? \\
& What is the policy problem? (What do we want to change or achieve?) \\
\hline Relationships & Who are the key 'stakeholders' (interested and affected parties)? \\
& What is the nature of the relationship between them? \\
& Are there existing agreements, contracts or treaties between the parties? \\
\hline Time & What time constraints do we face? \\
& What time trends can we observe, and what are the implications of those trends \\
& now and in the future? \\
& How are costs and benefits currently allocated between past, present and future \\
& generations?
\end{tabular}

\section{MULTI-CRITERIA COMPARATIVE ASSESSMENT OF POLICY OPTIONS}

\begin{tabular}{|c|c|c|c|c|}
\hline Criterion & Status quo & Option 1 & Option 2 & Option 3 \\
\hline \multicolumn{5}{|l|}{ FAIR PROCESS } \\
\hline \multicolumn{5}{|l|}{ Impartiality } \\
\hline \multicolumn{5}{|l|}{ Deliberative fairness } \\
\hline \multicolumn{5}{|l|}{ Transactional fairness } \\
\hline \multicolumn{5}{|l|}{ Transitional fairness } \\
\hline Assessment of procedural fairness & & & & \\
\hline
\end{tabular}

\section{FAIR OUTCOMES}

\begin{tabular}{c|l|l|l|l|}
\hline Assessed against the five dimensions of the Living Standards Framework & \multicolumn{1}{l}{} \\
\hline Economic growth & & & & \\
\hline Sustainability for the future & & & & \\
\hline Increasing equity & & & & \\
\hline Social infrastructure & & & & \\
\hline Reducing risks & & & & \\
\hline
\end{tabular}

And/or assessed against an agreed set of values, for example:

\begin{tabular}{l|l|l|l|l|}
\hline Freedom & & & & \\
\hline Equity & & & & \\
\hline Efficiency & & & & \\
\hline Reciprocity & & & \\
\hline Assessment of outcome fairness & & & & \\
\hline OVERALL ASSESSMENT & & & & \\
\hline
\end{tabular}

one another's motives' (Barry, 1995, p.51).

\section{A matrix for comparative assessment}

Table 1 summarises the approach I am proposing to the comparative assessment of policy options and the justification of 'a fair go' in public policy.

While assessment of options against each criterion should be quantified where possible, this matrix is offered not as a tool for technocrats to employ behind closed doors in a misguided attempt to design 'perfect systems', but as a framework to guide public deliberation ('things to think and talk about'). Quantification can and should inform public policy-making, but empirical analysis is not the cure for all

Central to 'a fair go' in public policy is what Cohen (1991) calls the interpersonal test, or what Sen (2009, pp.xii-xiii) means by 'public reasoning'. The approach outlined in this article intends to support citizen engagement and deliberation, through a public exchange of reasons, on practicable options to make our life together fairer than it is now:

the fact that fairness norms do not work like utopian thinkers would like them to work should not discourage us from trying to use them in the manner in which they actually do work. Others are free to toy with policy ills. ${ }^{8}$ grandiose plans to convert our planet into a new Jerusalem, but bourgeois liberals like myself are content to aim at finding workable ways of making life just a little bit more bearable for everyone. (Binmore, 2008, p.332)

1 Cf. the Commission's own excellent background paper on 'the citizenship dividend' (CFLRI, 2012).

2 As Rawls (2005, p.4) noted: 'The political culture of a democratic society is always marked by a diversity of opposing and irreconcilable religious, philosophical, and moral doctrines. Some of these are perfectly reasonable, and this diversity among reasonable doctrines political liberalism sees as the inevitable long-run result of the powers of human reason at work within the background of enduring free institutions.'

3 For example, Milton Friedman's 'Fair versus free' argues uncompromisingly for the priority of liberty: 'There is a real role for fairness, but that role is in constructing general rules and adjudicating disputes about the rules, not in determining the outcomes of our separate activities' (Friedman, 1992).

4 Analysis courtesy of Adrienne Fletcher, Knowledge Services, Ministry of Social Development. The Mana Party was formed in April 2011 following Hone Harawira's resignation from the Mäori Party. The Progressive Party did not contest the 2011 election.

5 In arguing (contra Rawls, 1971, pp.65, 101-04) that "justice itself requires us to reward superior performance in a suitable manner', Harsanyi nevertheless concurs with Rawls that 'we must not crate nodless economic and social in and maintains that 'such a policy would be fully compatible and maintains that 'such a policy would be fully compatible
with significantly smaller economic and social inequalities than we have today' (Harsanyi, 2008, p.76).

6 Fleurbaey and Maniquet do not treat efficiency as a criterion of fairness; rather, they introduce considerations of fairness into welfare economics as a useful way of addressing 'second-best policy problems'. In defining social ordering functions, efficiency is their central value (Fleurbaey and Maniquet, 2011, pp.22, 234).

7 Zajac notes $(1995$, pp.14, 77) that the relationship of Pareto efficiency to fairness is a crucial issue, for at least three reasons:

- strict Pareto optimality rarely exists: almost every policy change generates some losers:

- if a Pareto-improving move were to be identified and implemented, how should gains from the exchange be divided?;

- Pareto optimality may be possible in a static, risk-free world with perfect information, but policy-making happens in a risky, dynamic world of imperfect information.

8 Chavas and Coggins (2003, p.226) report that, on thei analysis, 'while better information typically generates improved efficiency, it can also contribute to unfair allocations. It also stresses the effects of asymmetric information in the evaluation of equity.'

\section{Acknowledgements}

In September 2013 members of the University of the Third Age (Golden Bay) provided feedback on an outline of the argument developed in this article, as did students in MAPP 523 (Politics, Philosophy and Public Policy) in the School of Government in October 2013. A number of staff at Environment Canterbury also read a draft and discussed it in a seminar in February 2014.

The author is grateful to Malcolm Menzies, Philip Devenish, Steve Gibling, David Shanks, Jonathan Boston and Michael Macaulay for their helpful review comments on earlier drafts. 


\section{References}

Alesina, A. and G.-M. Angeletos (2005) 'Fairness and redistribution', American Economic Review, 95 (4), pp.960-80

Almås, I. et al. (2010) 'Fairness and the development of inequality acceptance', Science, 328, pp.1176-8, doi: 10.1126/ science. 1187300

Anderson, E. (1999) 'What is the point of equality?', Ethics, 109 (2), pp.287-337

Arvan, M. (2014) 'First steps toward a nonideal theory of justice', Ethics and Global Justice (forthcoming), accessed March 2014 from http:// philpapers.org/archive/ARVFST.pdf

Atkinson, A. (1983) Social Justice and Public Policy, Brighton: Wheatsheaf Books

Barry, B. (1995) Justice as Impartiality, Oxford: Clarendon Press/New York: Oxford University Press

Berlin, I. (1969) Four Essays on Liberty, London/New York: Oxford University Press

Binmore, K. (2008) 'Naturalizing Harsanyi and Rawls', in M. Fleurbaey, M. Salles and J. Weymark (eds), Justice, Political Liberalism, and Utilitarianism: themes from Harsanyi and Rawls, Cambridge: Cambridge University Press

Boston, J. (2013) 'The quest for the good society: economics, ethics and public policy', paper prepared for a Treasury seminar, Wellington, 12 July 2013, accessed Mar 2014 from Australian Policy Online, http:// apo.org.au/sites/default/files/docs/IGPS_The-good-society_2013.docx

Bradstock, A. (2010) 'Using God-talk in a secular society: time for a new conversation on public issues', University of Otago Winter Lecture, accessed Mar 2014 from http://www.otago.ac.nz/ctpi/otago015731.pdf

Bradstock, A. (2012) 'In search of the good society: theology, secularism and the importance of vision', accessed Mar 2014 from http://www. otago.ac.nz/prodcons/groups/public/@theologypublicissues/documents/ webcontent/otago035324.pdf

Bräuer, J. and D. Hanus (2012) 'Fairness in non-human primates?', Social Justice Research, 25 (3), pp.256-76, doi: 10.1007/s11211012-0159-6

Bromell, D. (2008) Ethnicity, Identity and Public Policy: critical reflections on multiculturalism, Wellington: Institute of Policy Studies, Victoria University of Wellington, available from http://ips.ac.nz/ publications/publications/show/247

Bromell, D. (2009a) 'Diversity and democracy', Policy Quarterly, 5 (4), pp.29-35

Bromell, D. (2009b) 'Recognition, redistribution and democratic inclusion', in R. Openshaw and E. Rata (eds), The Politics of Conformity in New Zealand, North Shore City: Pearson

Bromell, D. (2011) What is Public Theology?, occasional paper, Centre for Theology and Public Issues, University of Otago, http://www.otago. ac.nz/ctpi/otago032508.pdf

Bromell, D. (2012) Evidence, Values and Public Policy, occasional paper, Australia and New Zealand School of Government, http://anzsog.edu. au/media/upload/publication/84_Bromell-Evidence-values-and-publicpolicy-for-ANZSoG-FINAL.pdf

Brosnan, S. and F. de Waal (2003) 'Monkeys reject unequal pay', Nature, 425, 18 September, pp.297-9, doi:10.1038/nature01963

CFLRI (2012) The Citizenship Dividend, accessed March 2014 from http://www.cflri.org.nz/sites/default/files/docs/RI-PP5-Citizenshipdividend-2012.pdf
CFLRI (2013) Commission for Financial Literacy and Retirement Income, Focusing on the Future: report to government. 2013 review of retirement income policy, accessed March 2014 from http://www. cflri.org.nz/retirement-income/policy-reviews

Chavas, J.-P. and J. Coggins (2003) 'On fairness and welfare analysis under uncertainty', Social Choice and Welfare, 20, pp.203-28

Clark, D. (2010) 'Killing the New Zealand dream', accessed March 2014 from http://www.davidclark.org.nz/2010/08/killing-the-new-zealanddream/

Cohen, G. (1991) 'Incentives, inequality, and community', Tanner Lectures on Human Values, Stanford University, May, accessed March 2014 from http://tannerlectures.utah.edu/_documents/a-to-z/c/ cohen92.pdf

Conrad, J. (1981) 'Where there's hope there's life', in D. Fogel and J. Hudson (eds), Justice as Fairness: perspectives on the justice model, Cincinnati, $\mathrm{OH}$ : Anderson Publishing Co.

Corning, P. (2011) The Fair Society: the science of human nature and the pursuit of social justice, Chicago: University of Chicago Press

Coyle, G. (2012) 'How does the operation of PHARMAC's "community exceptional circumstances" policy align with the distributive justice principles of fairness and equity as described by John Rawls and Amartya Sen?', PhD thesis, Auckland University of Technology, accessed March 2014 from http://aut.researchgateway.ac.nz/ bitstream/handle/10292/4563/CoyleG. pdf?sequence $=22$

Crockett, M. (2009) 'The neurochemistry of fairness: clarifying the link between serotonin and prosocial behaviour', Annals of the New York Academy of Sciences, 1167: Values, empathy, and fairness across social barriers, pp.76-86

Dworkin, R. (1981) 'What is equality? Part 2: equality of resources', Philosophy and Public Affairs, 10 (4), pp.283-345

Etzioni, A. (2014) 'Humble decision-making theory', Public Management Review, doi: 10.1080/14719037.2013.875392

Fehr, E. and K. Schmidt (2003) 'Theories of fairness and reciprocity: evidence and economic applications', in M. Dewatripont, L. Hansen and S. Turnovsky (eds), Advances in Economics and Econometrics: theory and applications, vol. 1, 8th World Congress of the Econometric Society, Cambridge: Cambridge University Press

Fischer, D. (2012) Fairness and Freedom: a history of two open societies - New Zealand and the United States, Oxford/New York: Oxford University Press

Fleurbaey, M. and F. Maniquet (2011) A Theory of Fairness and Social Welfare, Cambridge: Cambridge University Press

Frankfurt, H. (1987) 'Equality as a moral ideal', Ethics, 98 (1), pp.21-43 Freiberg, A. and W. Carson (2010) 'The limits to evidence-based policy: evidence, emotion and criminal justice', Australian Journal of Public Administration, 69 (2), pp.152-64, doi: 10.1111/j.14678500.2010.00674.x

Friedman, M. (1992) 'Fair versus free', Newsweek, 4 July 1977, accessed March 2014 from http://fff.org/explore-freedom/article/fairfree/

Gauss, G. (2010) 'The demands of impartiality and the evolution of morality', in B. Feltham and J. Cottingham (eds), Partiality and Impartiality: morality, special relationships, and the wider world, Oxford: Oxford University Press

Gazzaniga, M. (2005) The Ethical Brain, New York: Dana Press 
Geiringer, C. and M. Palmer (2003) 'Issues paper: applying a rightsbased analysis to the development of social policy in New Zealand', Wellington: New Zealand Centre for Public Law, accessed March 2014 from http://www.victoria.ac.nz/law/centres/nzcpl/publications/ other-publications/publications/Rights_and_Policy.pdf

Geiringer, C. and M. Palmer (2007) 'Human rights and social policy in New Zealand', Social Policy Journal of New Zealand, 30, pp.12-41, accessed March 2014 from http://www.msd.govt.nz/about-msd-andour-work/publications-resources/journals-and-magazines/social-policyjournal/spj30/30-human-rights-and-social-policy-in-new-zealandpages 12-41.html

Guest, R. (2013) Comparison of the New Zealand and Australian Retirement Income Systems: background paper prepared for the 2013 review of retirement income policy by the Commission for Financial Literary and Retirement Income, Wellington: Commission for Financial Literacy and Retirement Income, accessed March 2014 from http://www.cflri.org.nz/sites/default/files/docs/RI-Review-2013Comparison\%20NZ\%20\%26\%20Aus\%20Retirement\%20Income\%20 Systems.pdf

Haidt, J. (2012) The Righteous Mind: why good people are divided by politics and religion, New York: Pantheon Books

Harsanyi, J. (2008) 'John Rawls's Theory of Justice: some critical comments', in M. Fleurbaey, M. Salles and J. Weymark (eds), Justice, Political Liberalism, and Utilitarianism: themes from Harsanyi and Raw/s, Cambridge: Cambridge University Press

Hausman, D. (2008) 'Fairness and social norms', Philosophy of Science, 75, pp.850-60

Honneth, A. (2004) 'Recognition and justice: outline of a plural theory of justice', Acta Sociologica, 47 (4), pp.351-64

Hooker, B. (2005) 'Fairness', Ethical Theory and Moral Practice, 8, pp.329-52

Hume, D. (1777) An Inquiry Concerning the Principles of Morals (first publ. 1751), accessed March 2014 from http://www.gutenberg.org/ ebooks/4320

Isbister, J. (2001) Capitalism and Justice: envisioning social and economic fairness, Bloomfield, CT: Kumarian Press

Kaplow, L. and S. Shavell (2002) Fairness Versus Welfare, Cambridge, MA: Harvard University Press

Kerr, R. (2005) 'Vote of thanks', in R. Epstein, Fairness in a Liberal Society, Wellington: New Zealand Business Roundtable

Kilgallon, S. (2013) 'Are some more equal than others?', Sunday Star Times, 27 March, p.A14, accessed March 2014 from http://www. stuff.co.nz/life-style/life/8227563/Are-some-of-us-more-equal-thanothers

Klosko, G. (1992) The Principle of Fairness and Political Obligation, Lanham, MD: Rowman \& Littlefield

Koch, T. (2002) Scarce Goods: justice, fairness, and organ transplantation, Westport, CT: Praeger

Laswell, H. (1950) Politics: who gets what, when, how, New York: Peter Smith

Levine, S. (2012) 'Political values', Te Ara - the encyclopedia of New Zealand, updated 29 May 2012, accessed March 2014 from http:// www.teara.govt.nz/en/political-values
McComas, K. and J. Besley (2011) 'Fairness and nanotechnology concern', Risk Analysis, 31 (11), pp.1749-61

Pearce, N. (2007) 'Fair rules: rethinking fairness', Public Policy Research, 14 (1), pp.11-22

Pettit, P. (2008) 'Republican political theory', in M. Fleurbaey, M. Salles and J. Weymark (eds), Justice, Political Liberalism, and Utilitarianism: themes from Harsanyi and Raw/s, Cambridge: Cambridge University Press

Pfaff, D. (2007) The Neuroscience of Fair Play: why we (usually) follow the Golden Rule, New York: Dana Press

Rashbrooke, M. (ed.) (2013) Inequality: a New Zealand crisis, Wellington: Bridget Williams Books

Rawls, J. (1971) A Theory of Justice, Cambridge, MA: Belknap Press of Harvard University Press

Rawls, J. (2001) Justice as Fairness: a restatement, ed. E. Kelly, Cambridge, MA/London: Belknap Press of Harvard University Press

Rawls, J. (2005) Political Liberalism (expanded edition), New York: Columbia University Press

Royal Commission on Social Policy (1988) The April Report. Volume II, Future directions. Report of the Royal Commission on Social Policy. Te Kōmihana a te Karauna mō ngā Āhuatanga-ā-Iwi, Wellington: Royal Commission on Social Policy

Salmond, A. (2012) Beyond the Binary: shifting New Zealand's mindset, inaugural Bishop Sir Paul Reeves Memorial Lecture, Holy Trinity Cathedral, Auckland, August, accessed March 2014 from http://www. leadershipnz.co.nz/Modules/LSDocumentManager/DocumentDownload. aspx? Documentld $=137$

Salmond, A. (2013) 'Time to defend democratic rights', New Zealand Herald, 14 March, p.A37

Sanfey, A. (2007) 'Social decision-making: insights from game theory and neuroscience', Science, 318, 26 October, pp.598-602, doi: 10.1126/science.1142996

Sen, A. (1977) 'Rational fools: a critique of the behavioral foundations of economic theory', Philosophy and Public Affairs, 6 (4), pp.317-44

Sen, A. (1999) Development as Freedom, New York: Knopf

Sen, A. (2009) The Idea of Justice, Cambridge, MA: Belknap Press of Harvard University Press

Simmons, A. (2010) 'Ideal and nonideal theory', Philosophy and Public Affairs, 38 (1), pp.5-36

Singer, P. (1982) The Expanding Circle: ethics, evolution and moral progress, Princeton: Princeton University Press

Stiglitz, J. (2013) 'Inequality is holding back the recovery', New York Times, 20 March, SR1, accessed March 2014 from http:// opinionator.blogs.nytimes.com/2013/01/19/inequality-is-holding-backthe-recovery/?_php $=$ true \&_type $=$ blogs\&_r $=0$

Treasury (2013) Higher Living Standards, Wellington: Treasury, accessed March 2014 from http://www.treasury.govt.nz/abouttreasury/ higherlivingstandards

Walzer, M. (1981) 'Philosophy and democracy', Political Theory, 9 (3), pp.379-99

Zajac, E. (1995) Political Economy of Fairness, Cambridge, MA: MIT Press 